\title{
Comparative Study on the Recognition of English-Only Classes by Native English Speakers in Korean and Taiwanese Elementary Schools*
}

\begin{abstract}
Seungbin Roh
Baekseok University, Korea

This study is a comparative research regarding English-only classes by native English speakers at the elementary schools in two countries, Korea and Taiwan. These two countries tried to introduce as well as adapt English education and policy toward globalization. First of all, the two initiated mandatory elementary English education and then acknowledged the significance of English CLT (Communication Language Teaching). Thus, curriculum and policy for English education based on globalization oriented to the introduction of English native speakers and English-only classes. Based on these situations, Korea created EPIK (English Program in Korea) and NEST (Native English Speaking Teacher) respectively for inviting English native teachers. In the similar educational conditions, the recognitions of elementary school students of Korea and Taiwan regarding on English-only classes by native English speakers showed the relatively meaningful results. Compared with Taiwanese students, first, Korean students have greater ability in understanding of English-only class. Second, Korean students respond that native English speaking teachers' class helps them improve English better. Third, Korean students tend to use Korean and English together to improve their understanding. Fourth, Korean students respond English-only class reduces fear about English. Fifth, Korean students experience less difficulties in communicating with native English speaking teachers due to culture differences. Korean elementary students relatively have a higher understanding rate about native English speaking teacher's class.
\end{abstract}

Keywords: English-only class, elementary English education and policy

\section{Introduction}

Globalization has made English a global language, which is broadly scattered and omnipresent for business, commerce, science and technology, the internet, entertainment, and even sports (Crystal, 2000). In other words, it is the process of increased interconnectedness among countries most notably in the areas of economics, politics, and culture. However, broad-spectrum issues on globalization mentioned above are unsuccessful to detain the complication and diversity of globalization itself because it takes place within the borders of a given society and cultural framework (Lee, 2011). To overcome this limitation, therefore, in-depth

\footnotetext{
* Acknowledgements: This study was supported by the 2015 Faculty Research Grant from Baeseok University; this statistical results were presented at the 2014 MEESO (Modern English Education Society) Summer Conference.

Seungbin Roh, assistant professor, Ph.D., College of Liberal Arts, Baekseok University.
} 
elucidation of localized globalization concerning social, political, economic, and historical factors in processing globalization of the given society need to be considered (Capella, 2000; Luke \& Luke, 2000). In this vein, Burbules and Torres (2000) used the terminology glocalization and focused on the implication for understanding the situated and local uniqueness and conditions. Glocalization, thus, serves as a means of combining the idea of globalization with that of local consideration.

As the importance as well as the necessity of English in accordance with the extent of awareness on globalization is getting bigger, it is natural to apply more involvement to the globalized English curriculum and instruction as a significant main subject, and to amplify the role of English in schools. Therefore, English language education has strongly stressed English language itself such as phonology, morphology, and syntax along with the English conversation. However, language education is a multifaceted social, political, and cultural practice beyond language itself. Language delivers ideas, cultures, meanings, and ideologies embedded in and related to the language itself. For an effective globalized English language teaching and learning, thus, language education should analyze not only English linguistic areas, but also the broader social and political areas. One of the social and political factors that influence language education is governmental policy (Lee, 2011). Language education tends to walk behind policy decisions made by governmental agenda. According to Dubin and Olshtain (1986) regarding language education by governmental policy, the international societies entered the so-called age of limitless competition and the importance of English has been more focused in order to survive in the face of stiff competition since the launch of WHO (World Health Organization). For these reasons, the purposes of teaching and learning English have been generally decided by the governmental needs and EFL (English as a Foreign Language) learners should learn obligatorily English. They continue that the government needs to accept the products of civilization and achieve own country benefits such as foreign trade, scientific technique and to further modernize economically. At this time, English is not optional, but necessary.

Nowadays English is the most widely-spoken language in the world. In order not to step behind in such a globalization and in response to it requiring stalwartly the magnitude of English, many Asian countries including Korea and Taiwan have introduced sizeable changes in their English language educations and policies. The representative focus of these changes is to start English education in public elementary schools (Butler, 2004; Nunan, 2003).

In the case of two countries such as Korea and Taiwan, the effect of globalization on English language policy and English early education is considerably persuasive. In view of English education policy of Korea, for example, President Yongsam Kim government (1993-1998) had used first catchphrase "globalization" so that its logic based on complex political viewpoints could give birth to elementary English education policy. President Daejung Kim government (1998-2003) introduced the significance of "informationization" and correlated it directly to English in order to subsist in the global market so that the recognition of the need in English has shaped in the mindset of Koreans (Lee, 2006). With these arguments, the Korean Department of Education made mandatory English as a necessary theme from elementary school in 1997 toward globalization. Since then, English class hours per week has changed several times but teaching English from third grade students did not change (The Korea Ministry of Education, 2007).

Investigating Taiwan English educational policy, the Taiwan Department of Education introduced first English as obligatory subject from fifth grade in 2001 and next year extended this to third grade. Taiwan 
indigenous departments of education voluntarily taught English class to first and second grades (Su, 2006). Such English policy and education for globalization in Taiwan are customarily centered on "de-Chinaization, against Chinaisation of Taiwan", which allows both indigenization and internationalization in Taiwan through language education policies targeting the notion of "footing in Taiwan, procuring an international view" (Chen, 2006). These were the educational policy that students should learn English from elementary schools in order to get better their English skills. In Korea, English has been introduced to elementary school as compulsory education from third grade in 1997 (Lee, 2006). In contrast, the Taiwan Department of Education introduced first English as necessary subject from fifth grade in 2001 and next year lengthened this to third grade. Taiwan local departments of education freely taught English class to first and second grades (Su, 2006). ${ }^{1}$

Such globalization policy is strongly linked to English education because English is regarded as the essential tool for South Koreans and Taiwanese to be globalized for economic advancement. It is indisputable that the dynamics of the growth of the global English language connects strongly with economic concerns. Hsieh (2010) states that Taiwan strives hard in obtaining international visibility in all aspects so that language education and educational economics taken by the government can determine the advantage and weaknesses toward national benefits. Therefore, such policymaking actions stalwartly support their importance on English language education rooted in the belief that English language would promote a country's growth and effectiveness in the globalized world. In the case of Korea, according to the report of the Samsung Economic Research Institute (SERI) in 2006, it is termed as "the nation's economic infrastructure", which asserts that Korean's incomplete fluency in English creates lost domestic and international opportunities.

The reason that this study compares Korean and Taiwanese elementary students was that both countries have many similarities in English education policies, especially focusing on globalization in political and economic aspects mentioned above. Besides English education and policy, two countries have something in common. First, Korea and Taiwan have achieved a mature liberal democracy after two experienced severe political history such as Japanese colonial rule and communism. Second, the two countries join the ranks of advanced economical countries in spite of natural resource poor countries (Nam, 2007). In the future, it is within bounds to say that these two countries need to cooperate and compete at the same time in the global race. Thus, the comparisons of elementary English education and policy, especially English-only classes by native speakers between the two are meaningful for English education and for globalization. The results might be helpful to understand and share the advantages and disadvantages on English education and policy objectively. Moreover, this study will find out English education policy to be localized in globalization-oriented English education and consider the importance of becoming globalization-based.

The purposes of this research, first of all, are to find out the recognition of English-only classes by native English speakers in Korean and Taiwanese elementary schools. In doing so, this research considers how native English speakers' English-only classes introduced for globalization is needed to be globalized for the situated and localized suitably in each country's educational purposes in terms of comparing the two. To do so, this research asks the following 10 questions regarding on native English speakers' English-only classes: (1) the degree of understanding for English-only classes; (2) management plan when uncomprehending the contents of

\footnotetext{
${ }^{1}$ Excerpted from Roh, S. (2014). Research on comparing the recognition of English education and policy of college students of three eastern Asian countries. English Language \& Literature Teaching, 20(1).
} 
English-only classes; (3) whether English-only classes are helpful or unhelpful for English ability improvement; (4) students native language availability in English-only classes; (5) whether the fear for English decreases or not in English-only classes; (6) the difficulty due to the cultural differences between English native speaker teacher and students; (7) the most helpful function among English listening, reading, writing, and speaking by English-only classes; (8) the preferred gender for English native speakers; (9) the important factor among qualifications of English native speakers; and (10) the most optimal environment for English learning.

\section{Literature Review}

Both countries recognized the significance of globalization as mentioned in the introduction above. This mind-set directly influenced the English curriculum and instruction focusing on the necessity of better effective English communicative abilities, especially, English speaking. Therefore, both governments introduced new English curricula accentuating the improvement of oral communicative skills so that the Communicative Language Teaching (CLT) approach has been promoted at the elementary school level (Butler, 2005). The aim of CLT is to develop language learners' communicative ability rather than merely concentrating linguistic ability such as the grammar/translation toward accuracy (Celce-Murcia \& Hills, 1988).

Moreover, those two countries English educational purpose includes fostering interest and confidences in English, which will enable them to understand and express fundamental English in daily life. Therefore, it is emphasized that spoken language (listening and speaking) is more important than written language education in order to understand English at a basic level (Korean Ministry of Education, 2007). This kind of result is based on the assertion that spoken language education should be performed at elementary education because there was a certain limit in effectively growing ability in necessary English use that was enforced in middle schools (Lee, 2011; Wang, 2009). In the case of Taiwan, before elementary English education was performed, their English education was very traditional-repetitious and form-based grammar practice, translation, pronunciation instruction (Chen, 2002, 2006; Zhang, 2004). These kinds of English education and studying strategies did not prepare Taiwanese English learners to use proper and effective English use in reality and daily communication. This English educational reality led Taiwanese English education in 1990 to whole language teaching approaches and communicative language teaching approaches ( $\mathrm{Su}, 2006)$. The Taiwanese Education Department in 1999 decided and performed elementary and middle grades English education programs based on an English education program that was announced in 1993 and 1994 (the program focuses on fostering communication skills) (Su, 2006). The core information says that the purpose of the English education is improvement in speaking and listening, and understanding cultures. Also the new elementary and middle grades English education goal is not accuracy or memorization, but on acquiring language fluency through meaningful communication ( $\mathrm{Su}, 2006)$.

However, implementing CLT in Asian socio-cultural contexts has faced difficulties (Lamie, 2004; Sullivan, 2000). These difficulties might be stem from the different ways of teaching and learning styles, that is, learner-centered as opposed to teacher-oriented which is the traditional Asian educational style. Moreover, the lack of Korean English teachers' communicative proficiency and training may also be the one of factors to hinder CLT's effectiveness in the classes (Butler, 2005). The greater the importance of CLT, the lesser the expectation of non-native English speaking teachers based on these difficulties for adjusting CLT in the classroom. This situation has led to the conclusion that the ideals and effectiveness of English-only classes by 
English native speakers have been naturally accepted in English Language Teaching (ELT) fields. Therefore, both countries initiated their English programs with English native speaking teachers, such as EPIK for Korea and NEST for Taiwan. For EPIK, the Korean Ministry of Education formed the EPIK in 1995 with the task to "improve the English speaking abilities of Korean students and teachers, to develop cultural exchanges, and to reform English teaching methodologies in Korea" (EPIK, 2005). ${ }^{2}$ EPIK is a mission that began in 1996 in response to the goal- motivated slogan of the Korean government. Native English (NS) teachers were requested to support EPIK on two levels to help Korean teachers of English as a Foreign Language. First, it was to increase their vernacular English competency, and second it was to efficiently educate Korean EFL students. Since EPIK, the Korean Ministry of Education has been proficient to recruit and hire NS teachers of English from six English-speaking countries - the United States, Canada, the U.K., Australia, New Zealand, and Ireland.

The contributions of NS teachers have lent to a speedy progression in Korean English education and a boundless enthusiasm to learn English. As a result, after the Korean Ministry of Education announced "expanded English education in elementary school", English education became an important subject such as Mathematics and Language Arts; moreover, the establishment of English villages and afterschool English institutions for young children are managed successfully because of the emphasis on the effectiveness of "English villages", "native speakers", and "early English education". Besides that, the Korean Ministry of Education announced and implemented five years inclusive countermeasures in 2007 in order to improve students' English communicative skills. Two noticeable issues are that giving chances of English-speaking environment experience to Middle school students by assigning one native English speaker to each school by 2010. In other words, the number of native English speaking teachers was 221 in 2004 and this will increase to 2,900 by 2010 , and they plan to spend about 0.1 million dollars. Also English education experience centers will be expanded as well as expansion of English camp programs, considering geographical availability and aspects of afterschool, weekend, vacation, and so on.

For NEST, a NEST program suggests to a language teacher a policy made by governments which produces the presence of native English teachers as a major source of English education in the school system (Sommers, 2004). Hsinchu city in the northern part of Taiwan began the original NEST (Native English Speaking Teacher) program in 2001 (Lou, 2007). Unlike EPIK, NEST is supported by their relevant city governments and non-state education organizations. As of 2007, 10 out of 25 municipalities in Taiwan have put into operation these NEST programs (Lou, 2007). According to the standards for NEST programs in Taiwan put up on the MOE (Ministry of Education) website (2003), there were a number of purposes for the NEST programs: (1) endorsing team work of English teaching and learning as well as a healthier English learning environment for students in isolated regions; (2) introducing resident English instructors to current ideas and views about English education through the collaboration of beliefs about teaching methods and materials amongst teachers at home and abroad; (3) improving students' learning and communication capabilities in English; and (4) making possible cultural exchange programs between Taiwan and other countries and expand other countries' understanding of Taiwanese society (MOE website, 2003).

\footnotetext{
${ }^{2}$ See http://www.epik.go.kr.
} 


\section{Research Method}

\section{Participants}

One hundred and five elementary school students participated in this study. Korean elementary school students are 60 and Taiwanese 45. They were all first grade to sixth grade who contributed to a questionnaire survey in Korea and Taiwan. Korean students who participated in the research included 60 from elementary schools in the Metropolitan area, and Taiwanese students who participated were 45 from Li-Xing elementary school in Wen-Shan area, Taipei City. If we took a look at the characteristics of participants country by country, For Korean student's females were $55.0 \%$, males students were $45.0 \%$, and the ages of 11 years old were $33.3 \%$, of 10 years old were $20.0 \%$, and of 12 years old were $18.3 \%$. Fourth graders were $28.3 \%$, third graders were $25.0 \%$, second and sixth grade were $15.0 \%$. For Taiwanese, females were $72.0 \%$, males were $28.0 \%$, ages of 12 years old were $42.9 \%$, 11 years old were $34.7 \%$, and 10 years old were $12.2 \%$. Sixth graders were $44.4 \%$, fifth graders were $40.0 \%$, and fourth graders were $8.9 \%$. For Korean female students, age of 11 years old, fourth graders' response ratio was the highest, and for Taiwanese students, 12 years old, sixth graders response ratio was the highest.

Table 1

Demographical Characteristics

\begin{tabular}{llllll}
\hline \multirow{2}{*}{ Division } & & \multicolumn{2}{c}{ Korea } & \multicolumn{2}{c}{ Taiwan } \\
\cline { 3 - 6 } Gender & Male & 27 & Percentage & Frequency & Percentage \\
& Female & 33 & 45.0 & 14 & 28.0 \\
& Total & 60 & 55.0 & 36 & 72.0 \\
& 8 & 2 & 100.0 & 50 & 100.0 \\
\hline \multirow{4}{*}{ Age } & 9 & 9 & 3.3 & 1 & 2.0 \\
& 10 & 12 & 15.0 & 1 & 12.2 \\
& 11 & 20 & 20.0 & 6 & 34.7 \\
& 12 & 11 & 33.3 & 17 & 42.9 \\
& 13 & 1 & 18.3 & 21 & 6.1 \\
& 14 & 8.3 & 1.7 & 0.0 \\
Grade & Total & 2 & 100.0 & 49 & 100.0 \\
& 1st & 9 & 3.3 & 0 & 0.0 \\
& 2nd & 15 & 15.0 & 1 & 2.2 \\
& 3rd & 17 & 25.0 & 2 & 4.4 \\
& 4th & 8 & 28.3 & 4 & 8.9 \\
& 5th & 9 & 13.3 & 18 & 40.0 \\
\hline
\end{tabular}

\section{Analysis Method}

Data collected for this research used encoding. It was conducted statistically by using SPSS (Statistical Product and Service Solutions) statistics program, and used Frequency analysis and descriptive statistics in order to analysis the data. 


\section{Analysis Result}

Questionnaire and response average comparison. The questionnaire ${ }^{3}$ consists of ten items in total. All the responses are quantitative questions, among them the four questions - understanding the rate of Native English speakers' class, how much it is helpful in improving English, how much a student is afraid of English after English class, and difficulty in communication due to lack of cultural difference - are analyzed because it is capable of comparing with quantitative a rate.

From the result of the average of Korean students (2.02) and Taiwanese students (2.31), it can be shown that there is a statistical difference in the response rate of the most important question "the understanding rate of native English speakers' class" out of all four questionnaires. There also was a statistical difference in response results of how much a student is afraid of the English language after English classes from the average of Korean students (2.13) and Taiwanese students (1.88). We decided that there was no difference in the remaining of two questions.

Table 2

\section{Response Statistic of Four Questions}

\begin{tabular}{|c|c|c|c|c|c|c|c|c|}
\hline \multirow{3}{*}{ Question } & \multicolumn{8}{|c|}{ Response statistic } \\
\hline & \multicolumn{4}{|c|}{ Taiwan } & \multicolumn{4}{|c|}{ Korea } \\
\hline & $\mathrm{N}$ & Average & SD & $\begin{array}{l}\text { Average } \\
\text { standard error }\end{array}$ & $\mathrm{N}$ & Average & SD & $\begin{array}{l}\text { Average } \\
\text { standard error }\end{array}$ \\
\hline $\begin{array}{l}\text { Understanding rate of Native } \\
\text { English speakers' class }\end{array}$ & 51 & 2.31 & .735 & .103 & 59 & 2.02 & .707 & .092 \\
\hline $\begin{array}{l}\text { How much it is helpful in } \\
\text { improving English }\end{array}$ & 51 & 2.22 & .832 & .117 & 60 & 2.18 & .911 & .118 \\
\hline $\begin{array}{l}\text { How much a student is afraid of } \\
\text { English after English class }\end{array}$ & 48 & 2.00 & 1.031 & .149 & 60 & 1.97 & 1.089 & .141 \\
\hline $\begin{array}{l}\text { Difficulty in communication due } \\
\text { to lack of cultural difference }\end{array}$ & 50 & 1.88 & .521 & .074 & 60 & 2.13 & .676 & .087 \\
\hline
\end{tabular}

Table 3

Comparison of Two Countries' Response to the Four Questions

\begin{tabular}{|c|c|c|c|c|c|c|c|c|}
\hline & \multirow{2}{*}{ EVA* } & \multicolumn{2}{|c|}{ Equal variation test of Levene } & \multicolumn{5}{|c|}{ T-test for the difference between two means } \\
\hline & & $\mathrm{F}$ & p-value & $\mathrm{t}$ & $\mathrm{DF}^{* *}$ & p-value & $\mathrm{AD}$ & SD \\
\hline \multirow{2}{*}{$\begin{array}{l}\text { Understanding rate of Native } \\
\text { English speakers' class }\end{array}$} & $\mathrm{O}$ & 3.538 & .063 & 2.156 & 108 & .033 & .297 & .138 \\
\hline & $\mathrm{X}$ & & & 2.150 & 104 & .034 & .297 & .138 \\
\hline \multirow{2}{*}{$\begin{array}{l}\text { How much it is helpful in } \\
\text { improving English }\end{array}$} & $\mathrm{O}$ & .213 & .645 & .194 & 109 & .847 & .032 & .167 \\
\hline & $\mathrm{X}$ & & & .195 & 108 & .845 & .032 & .166 \\
\hline \multirow{2}{*}{$\begin{array}{l}\text { How much a student is afraid of } \\
\text { English after English class }\end{array}$} & $\mathrm{O}$ & .469 & .495 & .162 & 106 & .872 & .033 & .206 \\
\hline & $\mathrm{X}$ & & & .163 & 103 & .871 & .033 & .205 \\
\hline \multirow{2}{*}{$\begin{array}{l}\text { Difficulty in communication due } \\
\text { to lack of cultural difference }\end{array}$} & $\mathrm{O}$ & 4.672 & .033 & -2.168 & 108 & .032 & -.253 & .117 \\
\hline & $X$ & & & -2.219 & 107 & .029 & -.253 & .114 \\
\hline
\end{tabular}

Notes. * Equal variation assumption; ** Degree of freedom.

\footnotetext{
${ }^{3}$ Response of understanding rate of native English speakers' class: (1) completely understand-(4) never understand; Response of how much it is helpful in improving English: (1) strongly helpful-(4) never helpful; Response of how much a student is afraid of English after English class: (1) reduced fear a lot-(5) increased fear in English; and Response of difficulty in communication due to lack of cultural difference : (1) experience often-(3) never experience.
} 
The list of questions ${ }^{4}$ and interrelationship among the questionnaires. The list of questions are 10 in total, and after searching the interrelationship among the questionnaires, it is shown that there were a relationship between understanding native-speakers' English class and analysis on the questions that have high correlation among the aspects listed above was additionally analyzed.

The following Table 4 is a table analyzing the correlation of the response to the question; it is possible to select a significant question. The next step is to approach the subject in depth with the 'understanding native that speakers teaching English through' questions together by a cross table analysis.

Table 4

Result of Searching Interrelationship Among Questionnaires

\begin{tabular}{|c|c|c|c|c|c|c|c|c|c|c|c|}
\hline & & Q1 & Q2 & Q3 & $\mathrm{Q} 4$ & Q5 & Q6 & Q7 & Q8 & Q9 & Q10 \\
\hline \multirow{3}{*}{1} & $\begin{array}{l}\text { Pearson } \\
\text { correlation }\end{array}$ & 1 & $.424^{* *}$ & $.452^{* *}$ & $.297^{* *}$ & $.491^{* *}$ & $-.256^{* *}$ & $-.220^{*}$ & .139 & -.015 & -.055 \\
\hline & $\begin{array}{l}\text { Significance } \\
\text { probability }\end{array}$ & & .000 & .000 & .002 & .000 & .007 & .022 & .169 & .877 & .577 \\
\hline & $\mathrm{N}$ & 110 & 109 & 110 & 109 & 107 & 109 & 108 & 99 & 108 & 107 \\
\hline \multirow{3}{*}{2} & $\begin{array}{l}\text { Pearson } \\
\text { correlation }\end{array}$ & $.424^{* *}$ & 1 & $.436^{* *}$ & $.262^{* *}$ & $.392^{* *}$ & -.048 & $-.409^{* *}$ & -.116 & -.075 & -.116 \\
\hline & $\begin{array}{l}\text { Significance } \\
\text { probability }\end{array}$ & .000 & & .000 & .006 & .000 & .620 & .000 & .257 & .444 & .236 \\
\hline & $\mathrm{N}$ & 109 & 109 & 109 & 108 & 106 & 108 & 107 & 98 & 107 & 106 \\
\hline \multirow{3}{*}{3} & $\begin{array}{l}\text { Pearson } \\
\text { correlation }\end{array}$ & $.452^{* *}$ & $.436^{* *}$ & 1 & $.455^{* *}$ & $.646^{* *}$ & $-.344^{* *}$ & $-.232^{*}$ & -.047 & -.025 & -.147 \\
\hline & $\begin{array}{l}\text { Significance } \\
\text { probability }\end{array}$ & .000 & .000 & & .000 & .000 & .000 & .015 & .644 & .795 & .130 \\
\hline & $\mathrm{N}$ & 110 & 109 & 111 & 110 & 108 & 110 & 109 & 100 & 109 & 108 \\
\hline \multirow{3}{*}{4} & $\begin{array}{l}\text { Pearson } \\
\text { correlation }\end{array}$ & $.297^{* *}$ & $.262^{* *}$ & $.455^{* *}$ & 1 & $.342^{* *}$ & -.138 & -.150 & -.127 & .149 & -.067 \\
\hline & $\begin{array}{l}\text { Significance } \\
\text { probability }\end{array}$ & .002 & .006 & .000 & & .000 & .151 & .121 & .210 & .123 & .495 \\
\hline & $\mathrm{N}$ & 109 & 108 & 110 & 110 & 107 & 109 & 108 & 99 & 108 & 107 \\
\hline \multirow{3}{*}{5} & $\begin{array}{l}\text { Pearson } \\
\text { correlation }\end{array}$ & $.491^{* *}$ & $.392^{* *}$ & $.646^{* *}$ & $.342^{* *}$ & 1 & $-.256^{* *}$ & -.165 & .016 & -.050 & -.136 \\
\hline & $\begin{array}{l}\text { Significance } \\
\text { probability }\end{array}$ & .000 & .000 & .000 & .000 & & .007 & .090 & .877 & .610 & .165 \\
\hline & $\mathrm{N}$ & 107 & 106 & 108 & 107 & 108 & 108 & 106 & 97 & 106 & 105 \\
\hline \multirow{3}{*}{6} & $\begin{array}{l}\text { Pearson } \\
\text { correlation }\end{array}$ & $-.256^{* *}$ & -.048 & $-.344^{* *}$ & -.138 & $-.256^{* *}$ & 1 & .081 & -.084 & .108 & .111 \\
\hline & $\begin{array}{l}\text { Significance } \\
\text { probability }\end{array}$ & .007 & .620 & .000 & .151 & .007 & & .404 & .406 & .264 & .253 \\
\hline & $\mathrm{N}$ & 109 & 108 & 110 & 109 & 108 & 110 & 108 & 99 & 108 & 107 \\
\hline \multirow{3}{*}{7} & $\begin{array}{l}\text { Pearson } \\
\text { correlation }\end{array}$ & $-.220^{*}$ & $-.409^{* *}$ & $-.232^{*}$ & -.150 & -.165 & .081 & 1 & .126 & $.290^{* *}$ & .027 \\
\hline & $\begin{array}{l}\text { Significance } \\
\text { probability }\end{array}$ & .022 & .000 & .015 & .121 & .090 & .404 & & .218 & .002 & .782 \\
\hline & $\mathrm{N}$ & 108 & 107 & 109 & 108 & 106 & 108 & 109 & 98 & 108 & 107 \\
\hline
\end{tabular}

\footnotetext{
${ }^{4}$ Question 1. Understanding native-speaker's class; Question 2. Dealing with native-speaker's class when misunderstand; Question 3. Whether English-only classes are helpful or unhelpful for English ability improvement; Question 4. Student using first language during English class; Question 5. Decrease in fear using English only during English class; Question 6. Communication problem with native-speaker teacher due to cultural difference; Question 7. The most helpful aspect of English only class; Question 8. Preference of English teachers' gender; Question 9. Important traits of native-speaker teachers; and Question 10. Best environment for learning English
} 


\begin{tabular}{|c|c|c|c|c|c|c|c|c|c|c|c|}
\hline \multirow{3}{*}{8} & $\begin{array}{l}\text { Pearson } \\
\text { correlation }\end{array}$ & .139 & -.116 & -.047 & -.127 & .016 & -.084 & .126 & 1 & .167 & $.233^{*}$ \\
\hline & $\begin{array}{l}\text { Significance } \\
\text { probability }\end{array}$ & .169 & .257 & .644 & .210 & .877 & .406 & .218 & & .098 & .021 \\
\hline & $\mathrm{N}$ & 99 & 98 & 100 & 99 & 97 & 99 & 98 & 100 & 99 & 98 \\
\hline \multirow{3}{*}{9} & $\begin{array}{l}\text { Pearson } \\
\text { correlation }\end{array}$ & -.015 & -.075 & -.025 & .149 & -.050 & .108 & $.290^{* *}$ & .167 & 1 & .135 \\
\hline & $\begin{array}{l}\text { Significance } \\
\text { probability }\end{array}$ & .877 & .444 & .795 & .123 & .610 & .264 & .002 & .098 & & .163 \\
\hline & $\mathrm{N}$ & 108 & 107 & 109 & 108 & 106 & 108 & 108 & 99 & 109 & 108 \\
\hline \multirow{3}{*}{10} & $\begin{array}{l}\text { Pearson } \\
\text { correlation }\end{array}$ & -.055 & -.116 & -.147 & -.067 & -.136 & .111 & .027 & $.233^{*}$ & .135 & 1 \\
\hline & $\begin{array}{l}\text { Significance } \\
\text { probability }\end{array}$ & .577 & .236 & .130 & .495 & .165 & .253 & .782 & .021 & .163 & \\
\hline & $\mathrm{N}$ & 107 & 106 & 108 & 107 & 105 & 107 & 107 & 98 & 108 & 108 \\
\hline
\end{tabular}

Understanding native-speaker's class. According to the result of understanding rate of native-speaker's class, Korean students responded "I understand moderately" the most with 66.1\%, and "I completely understand" with 18.6\%, "I understand by action (body language)" with 10.2\%, and "I don't understand at all" with $5.1 \%$. Taiwanese students were similar to Korean students that they responded "I understand moderately" the most with $60.8 \%$, then "I completely understand" with $23.5 \%$, "I completely understand" and "I don't understand at all" had same result with $7.8 \%$. As a result, Korean students understand English class better than Taiwanese students do.

Table 5

Understanding Rate of Native Speaker's Class

\begin{tabular}{lllll}
\hline \multirow{2}{*}{ Division } & \multicolumn{2}{c}{ Korea } & \multicolumn{2}{c}{ Taiwan } \\
\cline { 2 - 5 } & Frequency & Percentage (\%) & Frequency & Percentage (\%) \\
\hline I understand completely. & 11 & 18.6 & 4 & 7.8 \\
I understand moderately. & 39 & 66.1 & 31 & 60.8 \\
I understand through words on board, actions such & 6 & 10.2 & 12 & 23.5 \\
as pictures or gestures by native speaker teachers. & 3 & 5.1 & 4 & 7.8 \\
I do not understand at all. & 39 & 100.0 & 51 & 100.0 \\
Total & 59 & & \\
\hline
\end{tabular}

Students dealing with problems when they do not understand native-speaker teacher's English classes. According to the result of students dealing with problems when they do not understand native-speaker teacher's English classes, Korean students responded the most to "ask the teacher directly" with $41.4 \%$ then "ask friends" with 32.8\%. Taiwanese students responded the most to "ask friends" with $49.0 \%$, then "ask the teacher directly" with $29.4 \%$. When students do not understand the class, Korean students tend to ask the teacher directly, but Taiwanese students tend to ask teachers.

Table 6

Students Dealing With Problem When They Do Not Understand Native-Speaker Teacher's English Class

\begin{tabular}{lllll}
\hline \multirow{2}{*}{ Division } & \multicolumn{2}{c}{ Korea } & \multicolumn{2}{c}{ Taiwan } \\
\cline { 2 - 5 } & Frequency & Percentage (\%) & Frequency & Percentage (\%) \\
\hline Ask teacher directly & 24 & 41.4 & 15 & 29.4 \\
Look for words on dictionary & 4 & 6.9 & 1 & 2.0
\end{tabular}




\begin{tabular}{lllll} 
Ask friends & 19 & 32.8 & 25 & 49.0 \\
Do nothing & 7 & 12.1 & 9 & 17.6 \\
Ask parents & 4 & 6.9 & 1 & 2.0 \\
Total & 58 & 100.0 & 51 & 100.0 \\
\hline
\end{tabular}

The result of analyzing students dealing with problem when they do not understand native-speaker teacher's English classes through cross table, both countries' students responded the most that "I understand moderately" when they choose to ask teacher directly. Students who responded "ask friends", 64\% Taiwanese students responded "I understand moderately" but 84.2\% $(10.5 \%+73.7 \%)$ of Korean students responded "I understand more than half of the material", which tells us that understanding rate is also high when they ask friends. Therefore, when the understanding rate is more than half way, it suggests that Korean students, just like Taiwanese students, know that communication with friends helps in learning.

Table 7

Students Dealing With Problems When They Do Not Understand Native-Speaker Teacher's English Classes Versus Understanding Rate of Native-Speaker Teacher's Classes Cross Table (Taiwan)

\begin{tabular}{llllll}
\hline Nationality Taiwan & Ask teacher directly & Look for words on dictionary & Ask friends & Do nothing & Ask parents \\
\hline I completely understand. & 3 & & & 1 & \\
I understand moderately. & 12 & 1 & $16(64 \%)$ & 1 & 1 \\
I understand through action. & & $7(28 \%)$ & 5 & \\
I do not understand at all. & & $2(8 \%)$ & 2 & \\
\hline
\end{tabular}

Table 8

Students Dealing With Problem When They Do Not Understand Native-Speaker Teacher's English Class Versus Understanding Rate of Native-Speaker Teacher's Class Cross Table (Korea)

\begin{tabular}{llllll}
\hline Nationality Korea & Ask teacher directly & Look for words on dictionary & Ask friends & Do nothing & Ask parents \\
\hline I completely understand. & 6 & 1 & $2(10.5 \%)$ & 2 & \\
I understand moderately. & 17 & 3 & $14(73.7 \%)$ & 2 & 2 \\
I understand through action. & 1 & & $3(15.8 \%)$ & & 2 \\
I do not understand at all. & & & 3 & \\
\hline
\end{tabular}

Whether English-only classes are helpful or unhelpful for English ability improvement. According to the result of whether English-only classes are helpful or unhelpful for English ability improvement, Korean students responded the most to "it helps" with $45.0 \%$, then "it strongly helps" with $23.3 \%$. Taiwanese students responded "it helps" with $45.1 \%$, which is the highest, then "it somewhat helps" with $29.4 \%$. Korean students responded more that native-speaker teacher's class helps in improving English skills, compared to Taiwanese students.

Table 9

Whether English-Only Classes Are Helpful or Unhelpful for English Ability Improvement

\begin{tabular}{lllll}
\hline \multirow{2}{*}{ Division } & \multicolumn{3}{c}{ Korea } & Taiwan \\
\cline { 2 - 5 } & Frequency & Percentage (\%) & Frequency & Percentage (\%) \\
\hline It strongly helps. & 14 & 23.3 & 10 & 19.6 \\
It helps. & 27 & 45.0 & 23 & 45.1 \\
It somewhat helps. & 13 & 21.7 & 15 & 29.4 \\
\hline
\end{tabular}




\begin{tabular}{lllll}
\hline It does not help at all. & 6 & 10.0 & 3 & 5.9 \\
Total & 60 & 100.0 & 51 & 100.0 \\
\hline
\end{tabular}

As a Cross Table result of whether English-only classes are helpful or unhelpful for English ability improvement and understanding rate of native English speaking teacher's classes, students responded that it helps when the understanding rate is more than half way in Taiwanese students' case with 29 students $(3+6+$ 20 ) out of 51 students, which is $56.9 \%$. In Korean students' case, it was $36(3+7+11+15)$ out of 59 students, which $61 \%$ that Korea students have a higher response in the homogeneity of understanding rate of native English speaking teacher's classes and improvement. Therefore, the relationship between the understanding rate of English class and English skills improvement is highly evaluated (Do you mean elevated?) for Korean students.

Table 10

Whether English-Only Classes Are Helpful or Unhelpful for English Ability Improvement Versus Understanding Native English Speaking Teacher's Classes Cross Table (Taiwan)

\begin{tabular}{lllll}
\hline Nationality Taiwan & It strongly helps & It helps & It somewhat helps & It does not help at all \\
\hline I understand completely. & 3 & & 1 & \\
I understand moderately. & 6 & 20 & 5 & 1 \\
I understand through action. & 1 & 3 & 7 & 2 \\
I do not understand at all. & & & 2 & 2 \\
\hline
\end{tabular}

Table 11

Whether English-Only Classes Are Helpful or Unhelpful for English Ability Improvement Versus Understanding Native English Speaking Teacher's Classes Cross Table (Korea)

\begin{tabular}{lllll}
\hline Nationality Korea & It strongly helps. & It helps. & It somewhat helps. & It does not help at all. \\
\hline I understand completely. & 3 & 7 & 1 & \\
I understand moderately. & 11 & 15 & 9 & 4 \\
I understand through action. & & 3 & 3 & 2 \\
I do not understand at all. & 1 & & 2 \\
\hline
\end{tabular}

Students using first language during English class. According to the result of students using first language during English class, Korean students responded the most to "sometimes students need to use first language" with $62.7 \%$, then "students can freely use first language" with $23.7 \%$.

Taiwanese students, just like Korean students, responded that "sometimes students need to use first language" the most with $52.9 \%$, then "students can never use first language" with $25.5 \%$

Compared to Korean students, Taiwanese students were more on the negative side in using first language during English class, and Korean students were more positive about using first language in English class.

Table 12

Students Using First Language During English Class

\begin{tabular}{lllll}
\hline \multirow{2}{*}{ Division } & \multicolumn{2}{c}{ Korea } & \multicolumn{2}{c}{ Taiwan } \\
\cline { 2 - 5 } & Frequency & Percentage (\%) & Frequency & Percentage (\%) \\
\hline Students can never use first language during English class. & 8 & 13.6 & 13 & 25.5 \\
Students sometimes need to use first language. & 37 & 62.7 & 27 & 52.9 \\
\hline
\end{tabular}




\begin{tabular}{lllll}
\hline Students can freely use first language in English class. & 14 & 23.7 & 11 & 21.6 \\
Total & 59 & 100.0 & 51 & 100.0 \\
\hline
\end{tabular}

According to the Cross Table result of the necessity of using first language during native English speaker teacher's classes and the understanding rate of English class, comparing case of students with more than a half way of understanding the class, Korean students (10) thought a stronger necessity of freely using a first language than Taiwanese students (4). Therefore, even though the understanding rate of English classes is high, Korean students feel it more necessary to use a first language in English class than unconditional banning first language usage. Therefore, this is what Korean students tend to prefer thus allowing first language usage in English classes in order to improve their understanding.

Table 13

First Language Usage Versus Understanding Rate of English Class Cross Table (Taiwan)

\begin{tabular}{llllllc}
\hline \multirow{2}{*}{ Nationality Taiwan } & \multicolumn{5}{c}{ Necessity of using first language in English class } \\
\cline { 2 - 7 } & \multicolumn{2}{c}{ Never use first language } & Okay to use first language & \multicolumn{2}{c}{ Freely use first language } \\
\cline { 2 - 7 } & Count & $\%$ & Count & $\%$ & Count & $\%$ \\
\hline Understand completely. & 2 & $50.0 \%$ & 2 & $50.0 \%$ & & $12.9 \%$ \\
Understand moderately. & 9 & $29.0 \%$ & 18 & $58.1 \%$ & 4 & $33.3 \%$ \\
Understand through action. & 1 & $8.3 \%$ & 7 & $58.3 \%$ & 4 & $75.0 \%$ \\
Do not understand. & 1 & $25.0 \%$ & & & 3 & \\
\hline
\end{tabular}

Table 14

First Language Usage Versus Understanding Rate of English Class Cross Table (Korea)

\begin{tabular}{lllllll}
\hline \multirow{2}{*}{ Nationality Korea } & \multicolumn{5}{c}{ Necessity of using first language in English class } \\
\cline { 2 - 7 } & \multicolumn{2}{c}{ Never use first language } & Okay to use first language & \multicolumn{2}{c}{ Freely use first language } \\
\cline { 2 - 7 } & Count & $\%$ & Count & $\%$ & Count & $\%$ \\
\hline Understand completely. & 3 & $27.3 \%$ & 5 & $45.5 \%$ & 3 & $27.3 \%$ \\
Understand moderately. & 5 & $13.2 \%$ & 26 & $68.4 \%$ & 7 & $18.4 \%$ \\
Understand through action. & & & 5 & $83.3 \%$ & 1 & $16.7 \%$ \\
Do not understand. & & & & & 3 & 100.0 \\
\hline
\end{tabular}

Decrease in fear about using English only during English class. According to the result of decrease in fear about using English only during English class, Korean students responded "it has reduced in fear" the most with $41.7 \%$, then "it somehow reduced fear" with $33.3 \%$, and "it reduced fear a little" with $16.7 \%$. Taiwanese students responded "it somehow reduced fear" with $43.8 \%$; "it greatly reduced fear" with $35.4 \%$; "it never reduced fear" with $10.4 \%$. Korean students, compared to Taiwanese students, said using English only during English class helps decrease in fear.

Table 15

Decrease in Fear About Using English Only During English Class

\begin{tabular}{lllll}
\hline \multirow{2}{*}{ Division } & \multicolumn{2}{c}{ Korea } & \multicolumn{2}{c}{ Taiwan } \\
\cline { 2 - 5 } & Frequency & Percentage & Frequency & Percentage \\
\hline Yes, it greatly reduced fear about English. & 25 & 41.7 & 17 & 35.4 \\
Yes, it somehow reduced fear about English. & 20 & 33.3 & 21 & 43.8 \\
Yes, it reduced fear about English a little. & 10 & 16.7 & 4 & 8.3 \\
\hline
\end{tabular}




\begin{tabular}{lllll}
\hline No, it has not reduced fear about English at all. & 2 & 3.3 & 5 & 10.4 \\
Rather, increased in fear using English. & 3 & 5.0 & 1 & 2.1 \\
Total & 60 & 100.0 & 48 & 100.0 \\
\hline
\end{tabular}

According to the Cross Table result of a decrease in fear about using English only during English class, Korean students feel less fear in English compared to Taiwanese students overall, but in the case of students who exhibit a good understanding rate during English class, a decrease in fear about using English in Taiwanese students was better than that of Korean students. Therefore, not only having a plan for increasing understanding rate, but also having a plan for reducing fear in English is necessary. ${ }^{5}$

Table 16

Decrease in Fear About Using English Only During English Class Versus Understanding Rate of Native English Speaking Teacher's Classes Cross Table (Taiwan)

\begin{tabular}{lllllllllll}
\hline \multirow{2}{*}{ Nationality Taiwan } & \multicolumn{3}{c}{ Greatly reduced } & \multicolumn{2}{c}{ Somehow reduced } & Reduced a little & Never reduced & \multicolumn{2}{c}{ Increased in fear } \\
\cline { 2 - 12 } & Count & $\%$ & Count & $\%$ & Count & $\%$ & Count & $\%$ & Count & $\%$ \\
\hline Understand completely. & 3 & 100.0 & & & & & & & \\
Understand moderately. & 12 & 40.0 & 15 & 50.0 & 3 & 10.0 & & & \\
Understand through action. & 1 & 9.1 & 6 & 54.5 & 1 & 9.1 & 3 & 27.3 & & \\
Never understand. & 1 & 25.0 & & & & & 2 & 50.0 & 1 & 25.0 \\
\hline
\end{tabular}

Table 17

Decrease in Fear Using English Only During English Class vs. Understanding Rate of Native English Speaking Teacher's Class Cross Table (Korea)

\begin{tabular}{lllllllllll}
\hline \multirow{2}{*}{ Nationality Korea } & \multicolumn{3}{c}{ Greatly reduced } & \multicolumn{3}{c}{ Somehow reduced } & \multicolumn{2}{c}{ Reduced a little } & Never reduced & \multicolumn{2}{c}{ Increased in fear } \\
\cline { 2 - 12 } & Count & $\%$ & Count & $\%$ & Count & $\%$ & Count & $\%$ & Count & $\%$ \\
\hline Understand completely. & 7 & 63.6 & 3 & 27.3 & 1 & 9.1 & & & & \\
Understand moderately. & 16 & 41.0 & 13 & 33.3 & 7 & 17.9 & 2 & 5.1 & 1 & 2.6 \\
Understand through action. & 2 & 33.3 & 3 & 50.0 & 1 & 16.7 & & & & \\
Never understand. & & & & 1 & 33.3 & & & 2 & 66.7 \\
\hline
\end{tabular}

Communication problem with native-speaker teachers due to cultural differences. According to the result of communication problems with native-speaker teachers due to cultural differences, Korean students responded the most to "sometimes" with $53.3 \%$, then "never" with $30 \%$, and "often" with 16.7. Taiwanese students, just like Korean students, responded to "sometimes" the most with $72.0 \%$, then "often" with $20.0 \%$, and "never" with $8.0 \%$.

Taiwanese students, compared to Korean students, experienced communication problems with native English speaking teachers due to cultural differences.

Table 18

Communication Problem With Native-Speaker Teachers Due to Cultural Differences

\begin{tabular}{llccc}
\hline \multirow{2}{*}{ Division } & \multicolumn{3}{c}{ Korea } & Taiwan \\
\cline { 2 - 5 } & Frequency & Percentage (\%) & Frequency & Percentage $(\%)$ \\
\hline
\end{tabular}

\footnotetext{
5 Taiwanese students understand moderately: 33 students/reduced in fear: 30 students (91\%); Korean students understand moderately: 50 students/reduced in fear: 39 students $(78 \%)$.
} 


\begin{tabular}{lllll}
\hline Experienced often. & 10 & 16.7 & 10 & 20.0 \\
Experienced sometimes. & 32 & 53.3 & 36 & 72.0 \\
Never experienced. & 18 & 30.0 & 4 & 8.0 \\
Total & 60 & 100.0 & 50 & 100.0 \\
\hline
\end{tabular}

According to the Cross Table results of communication problems with native-speaker teachers due to cultural differences, Korean students, compared to Taiwanese students, had experiential differences of cultural differences which were low in prior results, but when comparing only those students with high a understanding rate, some Korean students experienced cultural differences more often than Taiwanese students. Therefore, Korean students need instruction on understanding cultural differences even to those students with high an understanding rate. ${ }^{6}$

Table 19

Communication Problem With Native-Speaker Teacher Due to Cultural Differences Versus Understanding Rate of English Native Speaker Teacher's Class Cross Table (Taiwan)

\begin{tabular}{llllllc}
\hline \multirow{2}{*}{ Nationality Taiwan } & \multicolumn{2}{c}{ Experienced often } & \multicolumn{2}{c}{ Experienced sometimes } & \multicolumn{2}{c}{ Never experienced } \\
\cline { 2 - 6 } & Count & Row \% & Count & Row \% & Count & Row \% \\
\hline Understand completely. & & $12.9 \%$ & 27 & $25.0 \%$ & 3 & $75.0 \%$ \\
Understand moderately. & 4 & $36.4 \%$ & 6 & $87.1 \%$ & & \multirow{2}{*}{$9.1 \%$} \\
Understand through action. & 4 & $50.0 \%$ & 2 & $54.5 \%$ & 1 & \\
Cannot understand. & 2 & & & & \\
\hline
\end{tabular}

Table 20

Communication Problem With Native-Speaker Teacher Due to Cultural Difference Versus Understanding Rate of English Native Speaker Teacher's Class Cross Table (Korea)

\begin{tabular}{lllllll}
\hline \multirow{2}{*}{ Nationality Korea } & \multicolumn{2}{c}{ Experienced often } & \multicolumn{2}{c}{ Experienced sometimes } & \multicolumn{2}{c}{ Never } \\
\cline { 2 - 7 } & Count & Row \% & Count & Row \% & Count & Row \% \\
\hline Understand completely. & 2 & $18.2 \%$ & 4 & $36.4 \%$ & 5 & $45.5 \%$ \\
Understand moderately. & 6 & $15.4 \%$ & 22 & $56.4 \%$ & 11 & $28.2 \%$ \\
Understand through action. & & & 5 & $83.3 \%$ & 1 & $16.7 \%$ \\
Cannot understand. & 1 & $33.3 \%$ & 1 & $33.3 \%$ & 1 & $33.3 \%$ \\
\hline
\end{tabular}

The most helpful aspect of English only classes. According to the result of the most helpful aspect of English only classes, Korean students responded the most with $25.4 \%$ that it helped in everything and also helped in speaking, then in listening and writing. However, there were $13.6 \%$ of students who responded that nothing helped. $24 \%$ of Taiwanese students responded that listening was most helpful while it was $14.0 \%$ for speaking and $2.0 \%$ for reading. There were $10.0 \%$ of students who responded that nothing helped, and none of the students responded that writing helped. The ratio of Korean students were higher than Taiwanese students who responded that nothing helped in using English only in English class.

\footnotetext{
${ }^{6}$ Taiwanese students understanding more than a half way: 35 students/students who experienced cultural differences often: 4 students (11\%); Korean students understanding more than a half way: 50 students/students who experienced cultural differences often: 8 students $(16 \%)$.
} 
Table 21

The Most Helpful Aspect of English Only Class

\begin{tabular}{lllll}
\hline \multirow{2}{*}{ Division } & \multicolumn{2}{c}{ Korea } & \multicolumn{2}{c}{ Taiwan } \\
\cline { 2 - 5 } & Frequency & $\%$ & Frequency & $\%$ \\
\hline Listening & 11 & 18.6 & 25 & 50.0 \\
Reading & 7 & 11.9 & 1 & 2.0 \\
Writing & 3 & 5.1 & 0 & 0.0 \\
Speaking & 15 & 25.4 & 7 & 14.0 \\
Helps in nothing & 8 & 13.6 & 5 & 10.0 \\
Helps in every aspect & 15 & 25.4 & 12 & 24.0 \\
Total & 59 & 100.0 & 50 & 100.0 \\
\hline
\end{tabular}

According to the Cross Table result of the most helpful aspect of English only classes and the understanding rate of native English speaking teacher's classes, it has a similar result as to the prior result. Therefore, in the case of students understanding half way, Korean students responded the most that speaking and everything else were helpful, while Taiwanese students responded that listening was helpful the most. Therefore, Korean students have a more positive result because the aspects of that area of help are diverse.

Taiwanese students understand more than a half way: 34 students/students who said listening was helpful: $16 \%(47 \%)$;

Korean students understand more than half way: 49 students/students who said speaking and everything else was helpful: 14 students $(78 \%)$.

Table 22

Decrease in Fear Using English Only During English Classes Versus Understanding Rate of English Native Speaker Teacher's Classes Cross Table (Taiwan)

\begin{tabular}{|c|c|c|c|c|c|c|c|c|c|c|c|c|}
\hline \multirow[t]{2}{*}{ Nationality Taiwan } & \multicolumn{2}{|c|}{ Listening } & \multicolumn{2}{|r|}{ Reading } & \multicolumn{2}{|c|}{ Writing } & \multicolumn{2}{|c|}{ Speaking } & \multicolumn{2}{|c|}{ Nothing helped } & \multicolumn{2}{|c|}{$\begin{array}{c}\text { Helped in every } \\
\text { aspect }\end{array}$} \\
\hline & $\mathrm{F}$ & $\%$ & $\mathrm{~F}$ & $\%$ & $\mathrm{~F}$ & $\%$ & $\mathrm{~F}$ & $\%$ & $\mathrm{~F}$ & $\%$ & $\mathrm{~F}$ & $\%$ \\
\hline Understand completely. & & & & & & & & & 2 & 50 & 2 & 50 \\
\hline Understand moderately. & 16 & 53.3 & & & & & 5 & 16.7 & & & 9 & 30 \\
\hline Understand through action & 9 & 75 & 1 & 8.3 & & & 1 & 8.3 & 1 & 8.3 & & \\
\hline Never understand & & & & & & & 1 & 25 & 2 & 50 & 1 & 25 \\
\hline
\end{tabular}

Table 23

Decrease in Fear Using English Only During English Classes Versus Understanding Rate of English Native Speaker Teacher's Classes Cross Table (Korea)

\begin{tabular}{|c|c|c|c|c|c|c|c|c|c|c|c|c|}
\hline \multirow[t]{2}{*}{ Nationality Korea } & \multicolumn{2}{|c|}{ Listening } & \multicolumn{2}{|r|}{ Reading } & \multicolumn{2}{|r|}{ Writing } & \multicolumn{2}{|c|}{ Speaking } & \multicolumn{2}{|c|}{ Nothing helped } & \multicolumn{2}{|c|}{$\begin{array}{c}\text { Helped in every } \\
\text { aspect }\end{array}$} \\
\hline & $\mathrm{F}$ & $\%$ & $\mathrm{~F}$ & $\%$ & $\mathrm{~F}$ & $\%$ & $\mathrm{~F}$ & $\%$ & $\mathrm{~F}$ & $\%$ & $\mathrm{~F}$ & $\%$ \\
\hline Understand completely. & 3 & 27.27 & 1 & 9.091 & & & 2 & 18.18 & & & 5 & 45.45 \\
\hline Understand moderately. & 4 & 10.5 & 3 & 7.895 & 3 & 7.895 & 12 & 31.6 & 7 & 18.42 & 9 & 23.68 \\
\hline Understand through action. & 2 & 33.33 & 3 & 50.0 & & & & & & & 1 & 16.67 \\
\hline Never understand. & 2 & 66.67 & & & & & & & 1 & 33.33 & & \\
\hline
\end{tabular}

Preference of English teachers' gender. According to the result of students' preference of English teachers' gender, Korean students responded the most to "does not matter" with $44.1 \%$, then female teacher 
with $39.0 \%$ and male teacher with $16.9 \%$. Just like Korean students, Taiwanese students responded the most to "does not matter" with $53.7 \%$, then female teachers with $31.7 \%$ and male students with $14.6 \%$.

Both Korean students and Taiwanese students responded the most that they do not have a preference on the gender of English teachers, and they prefer female teachers over male teachers.

Table 24

Preference of English Teachers' Gender

\begin{tabular}{lllll}
\hline \multirow{2}{*}{ Division } & \multicolumn{2}{c}{ Korea } & \multicolumn{2}{c}{ Taiwan } \\
\cline { 2 - 5 } & Frequency & Percentage (\%) & Frequency & Percentage (\%) \\
\hline Male & 10 & 16.9 & 6 & 14.6 \\
Female & 23 & 39.0 & 13 & 31.7 \\
Does not matter & 26 & 44.1 & 22 & 53.7 \\
Total & 59 & 100.0 & 41 & 100.0 \\
\hline
\end{tabular}

Important traits of native-speaker teachers. According to the results concerning important traits of native-speaker teachers, Korean students responded the most to the "ability and knowledge to teach English" with $44.1 \%$, then personality with $37.3 \%$ and pronunciation with $16.9 \%$. Taiwanese students responded that personality is the most important trait with $36.7 \%$, then pronunciation with $32.7 \%$, and ability and knowledge to teach English was next with $18.4 \%$

Both Korean and Taiwanese students' response rate in personality was the lowest in this area about the important traits of native-speaker teachers. The ratio of Taiwanese students was higher than Korean students.

Table 25

Important Traits of Native-Speaker Teachers

\begin{tabular}{lllll}
\hline \multirow{2}{*}{ Division } & \multicolumn{2}{c}{ Korea } & Taiwan \\
\cline { 2 - 5 } & Frequency & Percentage (\%) & Frequency & Percentage (\%) \\
\hline Pronunciation & 10 & 16.9 & 16 & 32.7 \\
Nationality & 1 & 1.7 & 6 & 12.2 \\
Personality & 22 & 37.3 & 18 & 36.7 \\
Ability and knowledge to teach English & 26 & 44.1 & 9 & 18.4 \\
Total & 59 & 100.0 & 49 & 100.0 \\
\hline
\end{tabular}

Best environment for learning English. According to the result about the best environment for learning English, Korean students responded that learning English from native English speaking teachers in their motherland was the best environment for learning English with 39.7\%, then learning English from teachers speaking their language in their motherland with $31.0 \%$. 34\% of Taiwanese students, which was the highest. These responded that the environment does not matter compared to learning English from teachers speaking their language in their motherland which was $30.0 \%$

Taiwanese students responded the most that "learning environment does not matter" with the highest response ratio, while Korean students responded the most to "learning English from native English speaking teachers in their motherland" with the highest response ratio. 
Table 26

Best Environment for Learning English

\begin{tabular}{lllll}
\hline Division & \multicolumn{2}{c}{ Korea } & Taiwan \\
\cline { 2 - 5 } & Frequency & Percentage (\%) & Frequency & Percentage (\%) \\
\hline $\begin{array}{l}\text { Learning English from teacher speaking their } \\
\text { language in their motherland }\end{array}$ & 18 & 31.0 & 15 & 30.0 \\
$\begin{array}{l}\text { Learning English from native English speaking } \\
\text { teacher in their motherland }\end{array}$ & 23 & 39.7 & 14 & 28.0 \\
$\begin{array}{l}\text { Learning English from native English speaking } \\
\text { teacher in English speaking country }\end{array}$ & 8 & 13.8 & 4 & 8.0 \\
Does not matter & 9 & 15.5 & 17 & 34.0 \\
Total & 58 & 100.0 & 50 & 100.0 \\
\hline
\end{tabular}

\section{Conclusion}

First, by taking a look at the understanding rate of native English speaking teacher's class, Korean students have greater ability in understanding native English speaking teacher's classes.

Second, when students are dealing with native-speaker's classes that they misunderstand, most Korean students ask the native English speaking teacher directly while Taiwanese students ask friends the most. Understanding rate is more than a half way, students who communicate with friends well, which helps students understand learning content better.

Third, considering whether English-only classes are helpful or unhelpful for English ability improvement, we see that Korean students, compared to Taiwanese students, responded that native English speaking teacher's class helps them improve English better. And the interrelationship between Korean students' understanding rate about English classes and improvement in English is higher than that of Taiwanese students.

Fourth, considering student using first language during English class, we see that Taiwanese students, compared to Korean students, were more negative about using their first language during English class, and Korean students were more positive about using their first language. Korean students tend to use first language and English together in order to improve their understanding.

Fifth, Korean students responded that using English only during English class reduces fear about using English only during English class. It is important to consider this in not only improving the understanding rate of English class but also the solutions in reducing the fear of using English.

Sixth, compared to Korean students, Taiwanese students experienced more difficulties in communicating with native English speaking teachers due to cultural differences. It is necessary to teach cultural difference to the students even if they understand the material well.

Seventh, there was a higher ratio of Korean students than Taiwanese students who thought that nothing helps when they are put into speaking English only English classes. There also was a positive result from Korean students who responded that they considered the helpful aspects of English education as numerous such as speaking.

Eighth, according to students' preference on the gender of teachers, both Korean and Taiwanese students responded the most that it does not matter, then those who preferred male after female. 
Ninth, for important traits of native-speaker teachers, Korean students responded that ability and knowledge to teach English is the most important trait, while Taiwanese students responded that personality is the most important trait. Nationality had the lowest response rate from both Korean and Taiwanese students, but Taiwanese students had a higher ratio.

Tenth, according to the result of the best environment for learning English, Taiwanese students responded that the environment does not matter when learning English but Korean students had the highest response rate about learning English form native English speaking teachers in their motherland.

Korean students, compared to Taiwanese students, relatively have a higher understanding rate about native English speaking teacher's class. Understanding class rate and skills improvement have high correlation, and classes in their first language, which helps in diverse aspect of English education such as speaking. However, even students who exhibit a respectable academic understanding rate have fears in cultural differences, which is higher than that of Taiwanese students. Therefore, important necessities such as extracurricular cultural activities and learning activities with friends, partially allowed the first language to be used in class rather than just focusing only on learning

\section{References}

Bultle, Y. (2005). Comparative perspectives towards communicative activities among elementary school teachers in South Korea, Japan and Taiwan. Language Teaching Research, 9(4), 423-446.

Bultler, Y. (2004). What level of English proficiency do elementary school teachers need to attain to teach EFL? Case studies from Korea, Taiwan, and Japan. TESOL Quarterly, 38(2), 245-278.

Burbules, N., \& Torres, C. (2000). Globalization and education: An introduction. In N. Burbules and C. Torres (Eds.), Globalization and education: Critical perspectives (pp. 1-26). New York: Routledge.

Capella, J. (2000). Globalization, a fading citizenship. In N. Burbules and C. Torres (Eds.), Globalization and education: Critical perspectives (pp. 227-251). New York: Routledge.

Celce-Murcia, M., \& Hills, S. (1988). Techniques and resources in teaching grammar. Oxford: Oxford University Press.

Chen, S. C. (2002). The spread of English in Taiwan: Changing uses and shifting attitudes. Taipei: Taipei Publishing Co., Ltd..

Chen, S. C. (2006). Simultaneous promotion of indigenization and internationalization: New language-in-education policy in Taiwan. Language and Education, 20(4), 322-337.

Crystal, D. (2000). Language death. Cambridge: Cambridge University Press.

Dubin, F., \& Olshtain, E. (1986). Course design: Developing programs and materials for language learning. Cambridge: Cambridge University Press.

EPIK. (2005). Retrieved from http://epik.knue.ac.kr/

Hsieh, P. T. J. (2010). The impact of globalization on foreign language education policy in Taiwan-Policy initiatives and industrial demand. The International Journal of Educational and Psychological Assessment, 5(2), 237-254.

Korean Ministry of Education. (2007). Foreign language curriculum, Seoul, Korea.

Lamie, J. M. ( 2004). Presenting a model of change. Language Teaching Research, 8(2), 115-142.

Lee, B. (2006). English education, what kinds of cloth do we have to wear? In and Out, 21, 281-298.

Lee, I. (2011). Teaching how to discriminate: Globalization, prejudice, and textbooks. Teacher Educatin Quarterly, 47-63.

Lou, W. H. (2007). A study of native English-speaking teacher programs in elementary schools in Taiwan. Asia Pacific Education Review, 8(2), 311-320.

Luck, A., \& Luke, C. (2000). A situated perspective on cultural globalization. In N. Burbules and C. Torres (Eds.), Globalization and education: Critical perspectives (pp. 275-297). New York: Routledge.

Nam, D. (2007). Korean Economic in International World. Samsung Economic Research Center.

Nunan, D. (2003). The impact of English as a global language on educational policies and practices in the Asia-Pacific Region. TESOL Quarterly, 37(4), 589-613. 
Roh, S. (2012). A study of the recognition of Korean elementary school students in comparion with Taiwanese students regarding creative English learning activities. The Korean Journal of Thinking Development, 8(2), 47-81.

Roh, S. (2014). Research on comparing the recognition of English education and policy of college students of three Eastern Asian countries. English Language \& Literature Teaching, 20(1), 157-184.

Sommers, S. (2004). Why native speaker teacher programs don't work? Retrieved July 30, 2005 from http://scottsommers.blogs.com/taiwanweblog/2004/10/index.html

$\mathrm{Su}, \mathrm{Y}$. C. (2006). EFL teachers'perceptions of English language policy at the elementary level in Taiwan. Educational Studies, $32(3), 265-283$.

Sullivan, P. N. (2000). Playfulness as mediation in communicative language teaching in a Vietnamese classroom. In J. P. Lantolf (Ed.), Sociocultural theory and second language learning (pp. 115-131). Oxford: Oxford University Press.

Taiwanese Ministry of Education. (2003). Report on the project of recruiting native English-speaking teachers: Policy goals and implementation. Retrieved from http://www.edu.tw/EDU_WEB/EDU_MGT/

Wang, C. (2002). Innovating teaching in foreign language contexts: The case of Taiwan, In S. J. Savignon (Ed.), Interpreting communicative language teaching (pp. 131-153). New Haver, CT: Yale University Press.

Zhang, Y. P. (2004). English as a foreign language teaching in Taiwan. Taizhong Teacher College Journal, 18(1), 79-90.

\section{Appendix: Sample Questionnaire}

1. How much do you understand the native English teacher's speech in class? ( )

1) I completely understand. 2) I understand moderately. 3) I understand roughly through the native English teacher's gestures, words written on board, pictures, and photos that teachers show.

2. How do you respond when you do not understand a native English speakers words or lecture during class? ( )

1) I ask the native English teacher directly. 2) I look it up in a dictionary. 3) I ask my classmates. 4) I do not ask any questions. (I leave unsaid) 5) I ask my parents after school.

3. Do you think that English-only classes by native English speaking teachers are helpful in improving for your English ability? ( )

(1) They are strongly helpful. 2) They are helpful. 3) They are helpful a little. 4) They are not helpful at all.

4. Do you think that students never use their native language during classes by English native speaker teachers? ( )

1) Students never use their native language during classes with native English speaking teachers and even friends. 2) Students need to use their native language in some degree. 3) Students need to use their native language freely.

5. Do you think that your fear of English is getting decreased through English-only classes by native English speaking teachers? ( )

1) Yes, I think fear of English has been decreased so much. 2) Yes, I think fear of English has been decreased in some degree. 3) Yes, I think fear of English has decreased a little. 4) No, I think fear of English has not decreased at all. 5) Rather, I think my fear of English has been increased.

6. Have you ever experienced a difficulty of communication with native English speaking teachers due to cultural differences during classes? ( )

1) I experienced it frequently. 2) I experienced it occasionally. 3) I did not experience it at all.

7. What area do you think is helpful in taking classes by native English speaking teachers? ( )

1) Listening 2) Reading 3) Writing 4) Speaking 5) Nothing 6) All of the above.

8. Which gender do you prefer as being your native English speaking teacher? ( )

1) Male 2) Female 3) It does not matter.

9. Which factor do you think is important for a good native English speaking teacher? ( )

1) Pronunciation 2) Nationality 3) Personality 4) English teaching ability and knowledge. 
10. Which environment is the best for learning English very well? ( )

1) To be taught English by a Korean/Taiwanese English teacher in Korea/Taiwan.

2) To be taught English by a native English speaking teacher in Korea/Taiwan.

3) To be taught English by a native English speaking teacher in English speaking countries.

4) It doesn't matter. 